\title{
An Empirical Study of the Effect of Online Comments on Consumer Buying Behavior
}

\author{
A. Selcuk Koyluoglu
}

\section{ABSTRACT}

\begin{abstract}
There are many factors that affect the buying decision of consumers, and online comments are very important among these factors. Online comments made by customers or users have a direct impact on buying decisions. For this reason, consumers carefully examine online comments from other customers or users to access more accurate and realistic information during the buying decision process. The aim of the study, which is built on this understanding, is to examine the effects of online comments on consumer buying behavior. For this purpose, the study was carried out at Selcuk University with a random sampling method using a google survey. A total of 400 people at the university were reached. In this way, the opinions of different segments including academics, university staff and students were asked. SPSS 22.0 program was used in the analysis of the collected data. Pearson correlation and multiple regression analyzes were used because the scale used in the study was a normal distribution and parametric tests were used. As a result, it was observed that as the positive perspective of the participants on consumer comments increased, buying behavior also increased. However, no significant relationship was found between attitude towards comment and buying behavior $(p>0.05)$. The fact that the study was carried out at a university and that it covers the entire university, from academicians to students, distinguishes the study from others and makes it significant. Future studies on this subject can be carried out on other segments of society.
\end{abstract}

Keywords: Consumer Buying Behavior, Consumer, Online Comment.
Submitted : January 18, 2022

Published : February 10, 2022

ISSN: 2507-1076

DOI: $10.24018 /$ ejbmr.2022.7.1.1272

\section{A. Selcuk Koyluoglu*}

Selcuk University, Konya, Turkey. ORCID: 0000-0003-0359-1443

(e-mail: selcuk641@gmail.com)

*Corresponding Author

\section{INTRODUCTION}

As a result of the technological transformation, there has been a radical change in the communication habits with the internet that surrounds the world. This situation enabled consumers to carry out their knowledge, thoughts and experiences through various channels on the internet, and this communication led to a sharing process on the internet. In this process, which is called electronic word of mouth, the most used communication channel is online consumer comments. In the marketing literature, online consumer comments have taken their place among the most important sources used in buying decisions (Chevalier and Mayzlin, 2006; Liu, 2006).

Consumers who do not have sufficient knowledge before buying behavior give more importance to the experiences of other consumers. The internet, which offers a huge pool of ideas about products and services with its wide user network, significantly supports consumers by eliminating this difficulty. Online communication tools such as forums, blogs and social networks can be listed as platforms that bring consumers together (De Valck et al., 2009).

According to Lee et al. (2008), consumer comments were a trend that was initially started by very few people to communicate online for providing information about products, but this gradually spread to a wider base and expanded far beyond the target audience.

It is thought that online consumer comments, which are eventually a personal user experience, will assist the sale at minimum cost for the consumer. In the field of marketing, it is frequently stated that they have the potential of a new service channel. Because, in terms of traditional marketing communication, it is not possible to perform this function with the mentioned cost. However, this situation, which requires serious costs in the traditional environment, can be realized at less cost in the online environment and makes success possible by creating a competitive advantage (Chen and Xie, 2008).

Consumers engage in some pre and post purchase activities on online platforms. First, they undertake a range of research initiatives through online communication tools. Because information such as comments, recommendations and evaluations on these platforms is important for a potential consumer who is on the eve of buying. Secondly, the information obtained after use is shared with other consumers. Thus, the interaction, which stands out among consumers, causes a change in consumer behavior. Therefore, this growing power in the field of marketing has attracted the attention of many researchers (Hennig-Thurau et al., 2004; Ho and Dempsey, 2010).

Researchers have specifically examined the effect of online consumer comments on business performance. Chevalier and Mayzlin (2006), Liu (2006) revealed that online consumer comments increase marketing product sales. Gruen et al. (2005) focused on the contribution to customer 
value and loyalty. Clemons et al. (2006), on the other hand, found out that online consumer comments are critically effective during the launch of a new product.

Consulting the experiences of other consumers before making a purchase decision is now more than a necessity. Therefore, the importance of online consumer comments also affects the studies in this field. The aim of the study, built on this understanding, is to examine the effects of comments made on the internet on consumer buying behavior. For this purpose, the study was carried out at Selcuk University with a random sampling method using a google survey. A total of 400 people within the university were reached. In this way, the opinions of different segments including academics, university staff and students were asked. SPSS 22.0 program was used in the analysis of the collected data. Pearson correlation and multiple regression analyzes were used because the scale used in the study was a normal distribution and parametric tests were used. As a result, it was observed that as the positive perspective of the participants on consumer comments increased, the buying behavior also increased. However, no significant relationship was found between attitude towards comment and buying behavior $(p>0.05)$. The fact that the study was carried out at a university and that the university covers the entire university, from academicians to students, distinguishes the study from others and makes it significant. There are various studies in the literature on online consumer comments. However, there is a limited number of studies on this subject for different segments of society. Therefore, this study contributes to the literature by filling this gap.

The study plan is as follows: The first part of the study is the introduction. The second part is where the theoretical framework of the study is drawn. The third part is the methodology section, which includes the purpose of the research, its models and hypotheses, the data collection method and tool, the population and the sample. The fourth part is the findings section in which the obtained data are presented through statistical analysis. In the fifth part, the conclusion and discussion are discussed in the context of the literature.

\section{THEORETICAL BACKGROUND}

\section{A. Online Consumer Comments}

Online consumer comments are the digital transfer of consumers' thoughts about the product. In these platforms, consumers share information about the strengths and weaknesses of products (Pollach, 2006). These posts, which are made in the form of text, include praise and complaints about the product. In this way, users can read the shares and comment as well (Zhang et al., 2010).

Online consumer comments, which have the potential to be considered as the first step of buying decisions, are gaining importance (Sachse and Mangold, 2011). Therefore, the websites where online consumer comments are shared have become the focus of attention by users and have gained a significant influence in the internet world Bronner and Hoog (2010) because consumers consider these sites as a serious source of information before and after buying decision. In a study conducted by Clare (2009), the most obvious indicator of this explanation is that $72 \%$ of the participants read online consumer comments. The features such as being informationoriented, user-centered and product performance-oriented make the comments even more attractive (Jalilvand et al., 2011). The fact that the internet can reach very large masses increases the diversity of users and makes it possible for different users to be involved in the process. This feature emphasizes the nature of online consumer comments as a mass communication instrument (Yee, 2006).

Consumers read these comments with the aim of minimizing the risks in the product they will buy. While buying products, they also aim to use both resources and time rationally. Efforts such as learning how to use the product, being a member of virtual groups and having sufficient knowledge about the price are also taken into account. (Khammash, 2008). In this respect, the advantages of online consumer comments can be listed as reflecting real consumer comments, being accessible, being diverse and different, having significant reviews, being measurable and reducing risk (Kwon et al., 2011).

Companies have not remained indifferent to the developments regarding online consumer comments. Productpoia.com, consumerreview.com and many more review sites have been established. These sites are valued as institutionalized comment sites. However, consumer evaluation sites such as amazon.com have also become widespread (Sparks and Browning, 2011). However, it is necessary to separate virtual meeting environments such as chat rooms and blogs from these sites because only opinions about the product are shared on online comment sites (Opoku and Khan, 2004).

\section{B. The Effect of Online Consumer Comments on Buying Behavior}

Studies on the subject in the literature support that online consumer comments have a strong impact on consumers' decision-making processes (Zhu and Zhang, 2010). Gao et al., (2006), found in their studies that professional comments are more effective than amateur comments. Hu et al., (2008) showed that online reviews on Amazon.com match the actual quality of the product. Petty and Cacioppo (1984), found that objective messages have stronger effects on changing consumer attitudes than subjective messages. Godes and Silva (2009), drew attention to the increase in the number of comments in the negative trend of social dynamics. Duan et $a l$. ., (2008), on the other hand, support this view. Therefore, Dellarocas (2006) prompted marketers to invest in a better scoring system.

Sun et al. (2006), stated that there is a preference difference between those who buy a product for the first time and those who buy it again, and suggested that the comment variance is effective on consumer decision. Senecal and Nantel (2004), made a comparison between consumers who follow the comments and those who do not read the comments when making a buying decision. As a result, it was revealed that consumers who read comments prefer online shopping twice as much. Zhu and Zhang (2010) found that $24 \%$ of users consult online comments before buying an offline service. Lee (2007), emphasized that online comments bring consumers closer to marketers and retailers. Zhu and Zhang (2010), found that users with more internet experience are more effective in online comments. According to Chen 
and Xie (2008), online consumer comments guide consumers in the right way and thus contribute to increasing sales.

On the other hand, negative comments can reduce sales. For example, negative comments, especially about niche products, reduce the sales of these products (Zhao et al., 2008). There are also studies suggesting that online reviews have no effect on sales. Chen et al. 2004, claimed that the valence of comments has no effect on future sales. For this research, amazon.com data was used.

\section{Methodology}

In the methodology part of the study, firstly, the aim and contribution of the research were emphasized. Secondly, information is given about the research model and hypotheses. Then, the data collection method and tool were mentioned. The methodology part was completed with the population and sample of the study.

\section{A. The Purpose of Study}

Consumers carefully examine other users' online comments to access accurate and realistic information for acting more rationally during buying decision process. Therefore, this study examines the effects of online comments on consumer buying behavior. The fact that the study is carried out at a university and that it covers all individuals at the university distinguishes the study from its counterparts in terms of its importance.

\section{B. Research Model and Hypotheses}

The research model was prepared by taking into account the studies in the literature. Figure 1 below is designed for the effect of consumer comments on buying behavior.

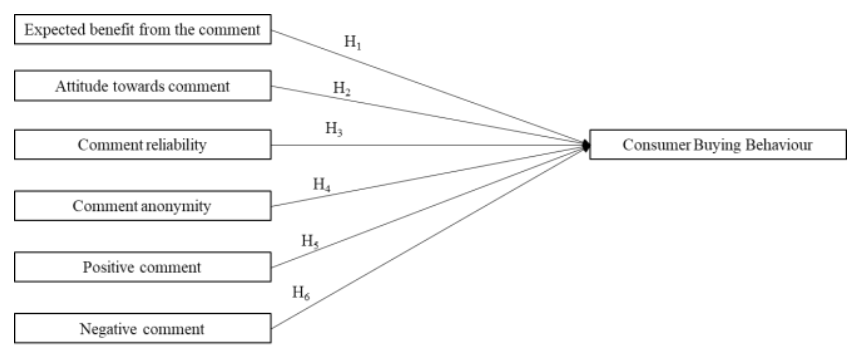

Fig. 1. Conceptual Model.

The hypotheses developed in this context can be listed as follows:

$\mathrm{H}_{1 \text { : }}$ There is a positive and significant relationship between the expected benefit from the comment and the consumer buying behavior (Bronner and Hoog, 2011).

$\mathrm{H}_{2 \text { : }}$ There is a positive and significant relationship between attitude towards comment and consumer buying behavior (Sachse and Mangold, 2011).

$\mathrm{H}_{3}$ : There is a positive and significant relationship between comment reliability and consumer buying behavior (Park and Lee, 2009).

$\mathrm{H}_{4}$ : There is a positive and significant relationship between comment anonymity and consumer buying behavior (Tong and Xuecheng, 2010).

$\mathrm{H}_{5}$ : There is a positive and significant relationship between positive comments and consumer buying behavior (Xavier and Summer, 2009).
$\mathrm{H}_{6:}$ There is a positive and significant relationship between negative comments and consumer buying behavior (Clare, 2009).

\section{The Data Collection Method and Tool}

In the study, the survey method was used for data collection. 5-point Likert Scale was used. The questionnaire form consists of 30 items and 4 parts. The benefit scale expected from the comments was classified as $(n=4)$, the attitude scale for comments was classified as $(n=4)$, comment reliability-comment anonymity-positive and negative comment scales were classified as $(n=7)$, and the consumer buying behavior scale was classified as $(n=15)$. The data were obtained in accordance with the model. SPSS 22.0 program was used in the analysis of the collected data. Since the scale used in the study was a normal distribution and parametric tests were used, descriptive and inferential statistics such as Pearson Correlation and Multiple Regression analyzes were used (Tabachnick and Fidell, 2013; George and Mallery, 2010)

\section{Population and Sample of the Study}

The study was carried out at Selcuk University with a random sampling method using a google survey. A total of 400 people at the university were reached. The study is within the $95 \%$ confidence interval and a 5\% margin of error is taken into account. In this way, the opinions of different segments including academics, university staff and students were asked.

\section{RESUlts}

\section{A. Analysis of Demographic Data}

The demographic characteristics of the participants are given in Table I:

\begin{tabular}{|c|c|c|c|}
\hline & Variables & $\mathrm{N}$ & $\%$ \\
\hline \multirow[t]{2}{*}{ Gender } & Female & 160 & 40,0 \\
\hline & Male & 240 & 60,0 \\
\hline \multirow[t]{3}{*}{ Age } & $18-25$ & 140 & 35,0 \\
\hline & $26-35$ & 128 & 32,0 \\
\hline & Between 35-50 & 132 & 33,0 \\
\hline \multirow[t]{4}{*}{ Income } & Less than $2500 \mathrm{TL}$ & 112 & 28,0 \\
\hline & $2500-4000 \mathrm{TL}$ & 176 & 44,0 \\
\hline & $4001-6000 \mathrm{TL}$ & 94 & 23,5 \\
\hline & $\begin{array}{c}\text { More than } 6000 \\
\text { TL }\end{array}$ & 18 & 4,5 \\
\hline Before buying a & $\mathrm{B} \log s$ & 77 & 17,1 \\
\hline product/service, mark the & Forums & 89 & 19,8 \\
\hline platform where you read the & Social Media & 199 & 44,3 \\
\hline internet comment with $(\mathrm{x})$. & complaint sites & 57 & 12,7 \\
\hline
\end{tabular}

As it is seen in Table I, $60 \%$ of the participants in the study were male and $40 \%$ were female. The number of male participants is higher than the number of female participants. The rate of participants in the $18-25$ age range is $35 \%$, the rate of participants in the $26-35$ age range is $32 \%$, and the rate of participants in the $35-50$ age range is $33 \%$. Therefore, it is understood that the number of young participants in the study is higher. In terms of income, the rate of participants with an income of less than $2500 \mathrm{TL}$ is $28 \%$, the rate of participants with an income between $2500-4000 \mathrm{TL}$ is $44 \%$, and the rate of participants with an income of 4001-6000TL is $4.5 \%$. In this context, it can be said that the participants mostly have a medium income. In terms of platforms where online comments are read, the number of participants reading 
comments on blogs is $17.1 \%$, the number of participants reading forums is $19.8 \%$, the number of participants reading comments on social media sites is $44.3 \%$, and the number of participants reading comments on complaint sites is $12.7 \%$. Accordingly, it is understood that the participants follow the comments on social media sites more than others.

\section{B. Reliability and Validity Analysis}

TABLE II: RELIABILITY OF THE SCALES USED IN THE RESEARCH

\begin{tabular}{lcc}
\hline \multicolumn{1}{c}{ Scales } & $\begin{array}{c}\text { Number } \\
\text { of items }\end{array}$ & $\begin{array}{c}\text { Cronbach's } \\
\text { Alpha }\end{array}$ \\
\hline $\begin{array}{l}\text { Expected Benefit from } \\
\text { comment }\end{array}$ & 4 & 0.865 \\
$\begin{array}{l}\text { Attitude towards comment } \\
\text { Comment Reliability }\end{array}$ & 4 & 0.804 \\
$\begin{array}{l}\text { Comment anonymity } \\
\text { Positive Comment }\end{array}$ & $15^{*} .871^{*}$ \\
$\begin{array}{l}\text { Negative Comment } \\
\text { Consumer Buying Behavior }\end{array}$ & 7 & 0.835
\end{tabular}

* The total number of items of the scales of comment reliability, comment anonymity, positive comments and negative comments is 15 , and Cronbach's Alpha values are .871 .

Table II shows the reliability of the scales used in the study. When the results are examined, it is understood that all the scales used in the study are "highly reliable" (>0.80). That is, the scale and dimensions are suitable for consistent and statistical analysis.

\section{Descriptive Statistics of Scales}

TABLE III: DESCRIPTIVE STATISTICS OF THE SCALES USED IN THE RESEARCH

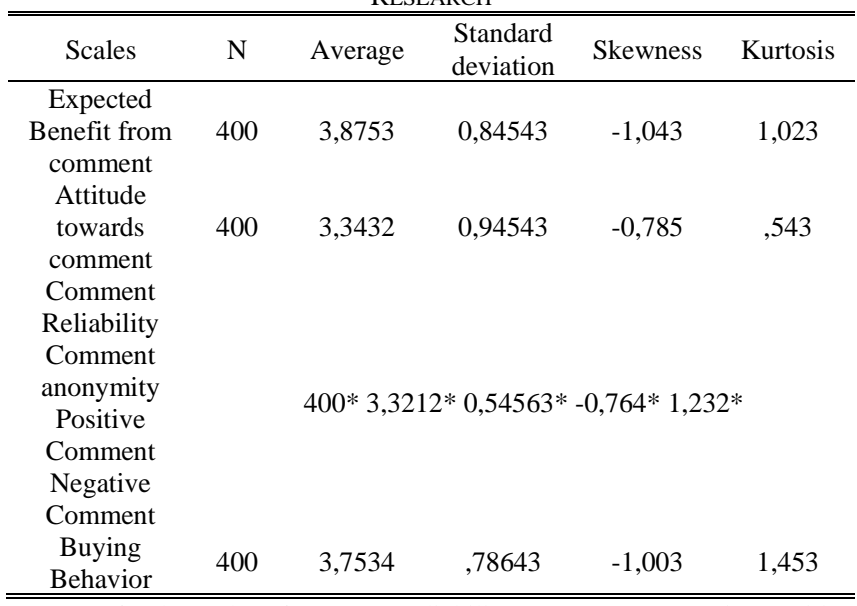

* $\mathrm{N}=400$ for the scales of comment reliability, comment anonymity, positive comments and negative comments, average: 3.3212 , std. deviation: .54563, skewness: -.764 , kurtosis: 1.232 .

In table III, the descriptive statistics of the scales used in the research are given. According to Tabachnick and Fidell (2013) and George and Mallery (2010), if the kurtosis and skewness values are between +1.5 and -1.5 , the scale is normally distributed and parametric tests should be used. Therefore, Pearson Correlation and Multiple Regression analyzes were used in the study.

\section{Pearson Correlation Analysis of the Relationship} Between Perspective on Consumer Comments and Consumer Buying Behavior

In Table IV, the relationship between perspective on consumer comments and buying behavior was tested with Pearson Correlation analysis. When the results of the analysis were examined, a positive and statistically significant relationship was found between the attitude towards the comment, expected benefit from the comment, the reliability of the comment, the anonymity of the comments, the positive and negative comments and buying behavior $(\mathrm{p}<0.05)$. This result reveals the existence of a linear correlation between consumer comments and buying behavior. In other words, as the positive attitude towards online comments increases, buying behavior also increases.

TABLE IV: The RELATIONSHIP BETWEen PERSPECTIVE ON CONSUMER COMMENTS AND BUYING BEHAVIOR

\begin{tabular}{cc}
\hline \hline Scales & Buying Behavior \\
\hline Expected Benefit from comment & $0,387^{* *}$ \\
Attitude towards comment & $0,301^{* *}$ \\
Comment Reliability & \\
Comment anonymity & $0,461^{(*)^{* *}}$ \\
Positive Comment & \\
Negative Comment & \\
\hline \hline
\end{tabular}

* It shows the ratio between review reliability, review anonymity, positive and negative review scales and buying behavior.

** It shows a statistically significant relationship.

\section{E. Regression Analysis of the Effect of Consumer Comments on Buying Behavior}

TABLE V: THE EFFECT OF CONSUMER COMMENTS ON BUYING BEHAVIOR

\begin{tabular}{|c|c|c|c|c|c|}
\hline \multirow{2}{*}{$\begin{array}{c}\text { Model } \\
\text { Dependent } \\
\text { variable: Buying } \\
\text { Behavior }\end{array}$} & \multicolumn{2}{|c|}{$\begin{array}{l}\text { Unstandardized } \\
\text { coefficients }\end{array}$} & \multirow{2}{*}{$\begin{array}{c}\begin{array}{c}\text { Standardized } \\
\text { coefficients }\end{array} \\
\text { Beta }\end{array}$} & \multirow{2}{*}{$\mathrm{T}$} & \multirow{2}{*}{$\mathrm{P}$} \\
\hline & B & $\begin{array}{l}\text { Std. } \\
\text { Error }\end{array}$ & & & \\
\hline (Constant) & 1,343 & 0,103 & & 7,341 & 0,000 \\
\hline $\begin{array}{l}\text { Expected Benefit } \\
\text { from comment }\end{array}$ & 0,187 & 0,031 & 0,253 & 5,331 & 0,000 \\
\hline $\begin{array}{l}\text { Attitude towards } \\
\text { comment }\end{array}$ & 0,032 & 0,021 & 0,042 & 0,802 & 0,575 \\
\hline $\begin{array}{l}\text { Comment } \\
\text { Reliability } \\
\text { Comment } \\
\text { anonymity } \\
\text { Positive } \\
\text { Comment } \\
\text { Negative } \\
\text { Comment }\end{array}$ & $0,354 *$ & $0,043^{*}$ & $0,501^{*}$ & $7,541 *$ & $0,000 *$ \\
\hline $\mathrm{P}$ & & & 0,000 & & \\
\hline $\mathrm{F}$ & & & 41,571 & & \\
\hline $\begin{array}{c}\text { Corrected } \\
\mathrm{R}^{2}\end{array}$ & & & 0,234 & & \\
\hline
\end{tabular}

* They are the values of the scales of comment reliability, comment anonymity, positive comments, and negative comments.

In Table $\mathrm{V}$, the effect of consumer comments on buying behavior was examined by regression analysis. As a result of the analysis, it was determined that the expected benefit from the comment, comment reliability, comment anonymity, positive and negative comments dimensions are effective on buying behavior $(\mathrm{p}<0,05)$. It can also be stated that as the positive perspective of the participants on consumer comments increases, buying behavior also increases. However, no significant relationship was found between attitude towards comment and buying behavior $(p>0,05)$. $23.4 \%$ of the changes in buying behavior are explained by online consumer comments.

\section{CONCLUSION}

\section{A. Conclusion}

Consumers want to get information before buying a product. This need is now being met quickly and easily with the developing technology. Because the developing technology has made the use of social networks more widespread and consumers who do not have the opportunity 
to learn what other consumers think about the product have had the chance to get information through these networks. This development has enabled a dynamic consumer profile to replace the stable consumer identity. Thus, online comments have managed to attract the attention of both the academic community and business professionals. In line with the studies conducted by marketing academics, it was confirmed that online comments are an important source of information for the consumer. The low cost, low risk and easy accessibility of online consumer platforms where reviews about products and services are shared increase this appeal. In this way, the consumer saves both resources and time.

As in other studies examining the effect of online comments on consumer buying behavior, statistical analyzes conducted in this study revealed a positive and statistically significant relationship between dimensions of online comments and buying behavior $(\mathrm{p}<0,05)$. This result reveals the existence of a linear correlation between consumer comments and buying behavior. In other words, as the positive attitude towards online comments increases, buying behavior also increases. A similar result was obtained with the last regression analysis. However, no significant relationship was found between attitude towards comment and buying behavior ( $p>0,05$ ). Finally, $23.4 \%$ of the changes in buying behavior are explained by online consumer comments.

\section{B. Limitations and Future Research}

The limitation of the study is that it was performed with 400 volunteer participants because increasing the number of samples may lead to different results. In addition, the design of the research in different cities or in different countries may contribute to this difference. The study was conducted at a university. With the inclusion of different segments of the society in the research, it may be possible to achieve both different and more realistic results. Since it is a quantitative study, statistical calculations were made with certain analyzes. More different analyzes can be used in future research. In addition to quantitative methods, study can also be conducted with qualitative methods. A comparative study can also be made between quantitative and qualitative methods in this regard. Elimination of the mentioned limitations for future research will increase the number of studies that will contribute more to the literature.

\section{Managerial Implications}

Online consumer comments provide companies with information about the level of consumer satisfaction. In this way, with the effect of leverage, companies can further strengthen their marketing activities. Difficulties in building a brand can be eliminated (Barton, 2006). Companies that include comments about the product have higher customer satisfaction and a lower product return rate. Underlying this is strong customer information satisfaction through online comments. Consumers who evaluate the product not only make positive comments but can also make negative comments. Thanks to negative comments, the manufacturer or retailer has the opportunity to further develop the product. At the same time, the reliability of the website is ensured. This is an indication that consumer trust has been gained (Voight, 2007).

Finally, as companies put more thought into online comments, they are able to form tighter bonds with consumers, can develop standards in this direction and increase their prestige with a more up-to-date identity (Gerzema and D'Antonio, 2011).

\section{REFERENCES}

Barton, B. (2006). Ratings, reviews \& ROI: How leading retailers use customer word of mouth in marketing and merchandising. Journal of Interactive Advertising, 7(1), 1-7.

Bronner, F. and Hoog, R. (2011). Vacationers and ewom: Who posts, and why, where, and what. Journal of Travel Research, 50(1), 15-26.

Chen, P. Y., Wu, S. Y. and Yoon, J. (2004). The impact of online recommendations and consumer feedback on sales. In Proceedings of The International Conference on Information Systems, Seattle, Association for Information Systems, 711-724.

Chen, Y. and Xie, J. (2008). Online consumer review: Word-of-mouth as a new element of marketing communication mix. Management Science, 54(3), 477-491.

Chevalier, J. A. \& Mayzlin, D. (2006). The effect of word of mouth on sales: Online book reviews. Journal of Marketing Research, 43(3), 345-354.

Clare, C. (2009). MRes extended abstract: Factors of online reviews that Influence consumer-buying decisions in b2c e-commerce. Doctoral Symposium, 1-8.

Clemons, E. K., Gao, G. and Hitt, L. M. (2006). When online reviews meet hyperdifferentiation: A study of the craft beer industry. Journal of Management Information Systems, 23(2), 149-171.

Dellarocas, C. (2006). Strategic manipulation of internet opinion forums: Implications for consumers and firms. Management Science, 52(10), 1577-1593.

DeValck, K., Bruggen, G. V. and Wierenga, B. (2009). Virtual communities: A marketing perspective, Decision Support Systems, 47, 185-203, 2009.

Duan, W., Gu B. and Whinston, A. B. (2008). Do online reviews matter? An empirical investigation of panel data. Decision Support Systems, 45(4), 1007-1016.

Gao, G., Gu, B. and Lin, M. (2006). The dynamics of online consumer reviews. Proceedings of the 7th International Conference on Web Information Systems, 1-6.

George, D. and Mallery, M. (2010). SPSS for Windows Step by Step: A Simple Guide and Reference, Boston.

Gerzema, J. and D'Antonio, M. (2011). Spend shift: How the postcrisis values revolution is changing the way we buy, sell, and live, San Francisco, Jossey-Bass.

Godes, D. and Silva, J. (2009). The Dynamics of online opinion. Working Paper, R. H. Smith School of Business, University of Maryland, USA.

Gruen, T. W., Osmonbeko, T. and Czaplewski, A. J. (2005). Ewom: The impact of customer-to-customer online know-how exchange on customer value and loyalty. Journal of Business Research, 59(4), 449456.

Ho, J.Y.C. and Dempsey, M. (2010). Viral marketing: Motivations to forward online content. Journal of Business Research, 63(9), 10001006.

Hu, N., Liu, L. and Zhang, J. (2008). Do online reviews affect product sales? The role of reviewer characteristics and temporal effects. Information Technology and Management, 9(3), 201-214.

Jalilvand, M. R., Esfahani, S. S. and Samiei, N. (2011). Electronic word-ofmouth: Challenges and opportunities. Procedia Computer Science, 3 , 42-46.

Khammash, M. (2008). Electronic word-of-mouth: Antecedents of reading customer reviews in on-line opinion platforms: A quantitative study from the UK market. IADIS International Conference, 77-84.

Kwon, J. M., Bae, J.I. and Phelan, K. (2011). Online consumer herding behaviors in the hotel industry. Presented at 16th Graduate Students Research Conference, Houston, Texas.

Lee, J., Do-Hyung, P. and Han, I. (2008). The effect of negative online consumer reviews on product attitude: An information processing review. Electronic Commerce Research and Applications, 7(3), 341352.

Lee, T. Y. (2007). Needs-based analysis of online customer reviews. Proceedings of the 9th International Conference on Electronic Commerce, Minneapolis, 311-318.

Liu, Y. (2006). Word of mouth for movies: Its dynamics and impact on box office revenue. Journal of Marketing Research, 70(3), 74-89.

Opoku, R. A. and Khan, M. N. (2004). Consumer feedback online, case studies of Swedish manufacturing SMEs. M. thesis, Dept. Business Administration and Social Sciences, Lulea University of Technology, Lulea, Sweden. 
Park, C. and Lee, T. M. (2009). Information direction, website reputation and ewom effect: A moderating role of product type. Journal of Business Research, 62(1), 61-67.

Petty, R. E. and Cacioppo, J. T. (1984). The effects of involvement on response to argument quantity and quality: Central and peripheral routes to persuasion. Journal of Personality \& Social Psychology, $46(1), 69-81$.

Pollach, I. (2006). Electronic word of mouth: A genre analysis of product reviews on consumer opinion web sites. Proceedings of the 39th Hawaii International Conference on System Sciences, Hawaii, 1-10.

Sachse, S. B. and Mangold, S. (2011). Brand equity dilution through negative online word-of-mouth communication. Journal of Retailing and Consumer Services, 18, 38-45.

Senecal, S. and Nantel, J. (2004). The influence of online product recommendations on consumers' online choices. Journal of Retailing, 80(2), 159-169.

Sparks, B. A. and Browning, V. (2011). The impact of online reviews on hotel booking intentions and perception of trust. Tourism Management, 32(6), 1-14.

Sun, T., Youn, S., Wu, G. and Kuntaraporn, M. (2006). Online word-ofmouth (or mouse): An exploration of its antecedents and consequence. Journal of Computer-Mediated Communication, 11(4), 1104-1127.

Tabachnick, B.G. and Fidell, L. S. (2013). Using Multivariate Statistics, Boston: Pearson.

Thurau, T.H., Gwinner, K. P., Walsh, G. and Gremler, D. D. (2004). Electronic word-of-mouth via consumer-opinion platforms: What motivates consumers to articulate themselves on the internet? Journal of Interactive Marketing, 18(1), 38-52.

Tong, W. and Xuecheng, Y. (2010). Electronic word of mouth in online social Networks. Second International Conference on Communication Systems, Hong Kong, China, 249-253.

Voight, J. (2007). Getting a handle on customer reviews. Adweek, 48(26), 16-17.

Xavier, L. J. W. and Summer, G. Y. S. (2009). Viral marketing communication: The internet word-of-mouth a study on consumer 116 perception and consumer response. M. thesis, Dept. Business Administration, School of Management Blekinge Institute of Technology, Sweden.

Yee, C. M. (2006). Do people believe electronic word-of mouth? A study on factors affecting readers' perceived credibility of online consumer reviews. M. S. thesis, City University, Hong Kong.

Zhang, Z., Ye, Q., Law, R. and Li, Y. (2010). The impact of e-word-of-mouth on the online popularity of restaurants: A comparison of consumer reviews and editor reviews. International Journal of Hospitality Management, 29(4), 694-700.

Zhao, X., Gu, B. and Whinston, A. B. (2008). The influence of online wordof-mouth long tail formation: An empirical analysis. In Proceedings of The Conference on Information Systems and Technology (CIST 2008), October 11-12, Washington, DC.

Zhu, F. and Zhang, X. (2010). Impact of online consumer reviews on sales: The moderating role of product and consumer characteristics. Journal of Marketing, 74(2), 133-138.

A. Selcuk Koyluoglu completed his master's degree in 2008 and his doctorate in 2016 in the department of business administration at Selcuk University. He is an expert in marketing science. He is still working as an Assistant Professor at Selcuk University. He has carried out many studies especially in the field of neuromarketing. In addition to this, consumer behavior, brand, advertising, etc. He has conducted many studies on other subjects of the field. It also takes part in interdisciplinary studies. In short, he has published engaging articles on a wide variety of topics that provide a platform for his ideas. He is therefore a frequent contributor to both respected academic journals and widely read commercial and general interest publications. 